\title{
PERSEPSI PRAKTISI PERBANKAN SYARIAH MENGENAI PENERAPAN TEKNOLOGI PREAUTHORIZED DEBIT SEBAGAI FEE BASED INCOME PADA BANK SYARIAH
}

\section{ISLAMIC BANKING PRACTITIONER PERCEPTIONS REGARDING APPLICATION OF TECHNOLOGY PREAUTHORIZED DEBIT AS FEE BASED INCOME ON ISLAMIC BANKING}

\author{
Rivan Abdurrahman'a; Rully Trihantana ${ }^{2} b$ \\ 1aProgram Studi Ekonomi Islam Fakultas Ekonomi Islam Universitas Djuanda, Jl. Tol Ciawi \\ No. 1, Kotak Pos 35 Bogor 16720 \\ 2b Program Studi Ekonomi Islam Fakultas Ekonomi Islam Universitas Djuanda, Jl. Tol Ciawi \\ No. 1, Kotak Pos 35 Bogor 16720
}

(Diterima oleh Dewan Redaksi 10-06-2016)

(Dipublikasikan oleh Dewan Redaksi 01-12-2016)

\begin{abstract}
This study aims to determine the perception of practitioners of Islamic banking on the application of technology preauthorized debit as fee-based income in Islamic banks. The method used in this research is quantitative descriptive sample of 45 practitioners of Islamic banking Bogor and Cianjur. Data analysis techniques using the Likert method and chi-square as a tool of analysis. The calculation result obtained in the study chi-square value calculated at 36.87 . It shows that the value of chi-square count is greater than the value of chi-square table (36.87> 7815). Thus $\mathrm{HO}$ and $\mathrm{H} 1$ accepted, meaning it can be concluded that the practitioners of Islamic banking is already known about the application of preauthorized debit in Islamic banks.
\end{abstract}

Keywords: Perception, Preauthorized debit, Fee Based Income, Islamic Bank.

\section{ABSTRAK}

Penelitian ini bertujuan untuk mengetahui persepsi praktisi perbankan syariah mengenai penerapan teknologi preauthorized debit sebagai fee based income pada bank syariah. Metode yang digunakan adalah deskriptif kuantitatif dengan sampel 45 orang praktisi bank syariah kota Bogor dan Cianjur. Teknik analisis data penelitian menggunakan metode skala likert dan chi-square sebagai alat analisisnya. Hasil perolehan perhitungan nilai chi-square hitung dalam penelitian adalah sebesar 36.87. Sedangkan nilai chi-square tabel diketahui sebesar 7.815. Hal tersebut menunjukkan bahwa nilai chi-square hitung lebih besar daripada nilai chi-square tabel $(36.87>7.815)$. Dengan demikian hipotesis H1 diterima, artinya dapat dibuat kesimpulan berarti para praktisi perbankan syariah sudah mengetahui mengenai penerapan preauthorized debit pada bank syariah.

Kata kunci : Persepsi, Preauthorized debit, Fee Based Income, Bank Syariah

Rivan Abdurrahman. 2016. Persepsi Praktisi Perbankan Syariah Mengenai Penerapan Teknologi Preauthorized Debit sebagai Fee Based Income Pada Bank Syariah. (5): 283 - 291 


\section{PENDAHULUAN}

Kegiatan ekonomi dimanapun saat ini berkaitan erat pengaruhnya dengan dunia perbankan. Oleh karenanya kegiatan bank dan perekonomian akan saling bermutualisme. Awal dari kegiatan perbankan yang hanya sebatas tempat penukaran uang, saat ini sudah sangat berkembang dengan pesat menjadi tempat menyimpan uang (tabungan), pembiayaan, transaksi keuangan, sampai pada transaksi keuangan termutakhir. Keadaan demikian sejalan dengan dibutuhkannya dunia perbankan dalam melaksanakan perekonomian. Maka dari itu, agar kegiatan ekonomi berjalan lancar, di era globalisasi ini bank dituntut untuk memberikan kemudahan, kenyamanan, dan keamanan kepada nasabahnya pada saat melakukan transaksi perbankan.

Pada zaman modern ini, terdapat banyak cara untuk memberikan kemudahan, keamanan, dan kenyamanan dalam bertransaksi di perbankan, salah satunya adalah pemanfaatan teknologi informasi perbankan yang terus mengalami perkembangan. Sebagai pihak berwenang dalam kebijakan moneter, Bank Indonesia juga telah mengeluarkan aturan mengenai Teknologi Sistem Informasi, yaitu PBI Nomor : 9/15/PBI/2007 tentang Penerapan Manajemen Risiko dalam Penggunaan Teknologi Informasi oleh Bank Umum, yang di dalamnya diatur berbagai prinsip yang perlu diperhatikan manajemen bank dalam pengelolaan teknologi informasi secara mandiri maupun dikelola dengan bantuan pihak lain. Dengan memanfaatkan teknologi secara optimal dan sesuai prosedur, maka tujuan perbankan agar dapat memberikan setiap nasabah kemudahan dapat tercapai.

Munculnya peluang atas beragam jenis bisnis perbankan yang transaksinya dapat dilakukan menggunakan cara elektronik sangat terikat dan tidak lepas dari berkembangnya teknologi. Contoh jenis transaksi elektronik perbankan $(e-$ banking) yang dapat memudahkan pengguna saat transaksi diantaranya adalah ATM, debit card, computer banking, direct deposit, direct payment, preauthorized debit, dan lain-lain. Jenisjenis transaksi tersebut dibentuk oleh perbankan semata-mata demi memenuhi keinginan serta kebutuhan masyarakat untuk mempermudah dalam menjalankan berbagai macam transaksi dengan mengikuti perkembangan teknologi modern

Seiring berjalannya waktu, saat ini kegiatan perbankan tidak dapat terlepas dari teknologi informasi dalam melaksanakan operasionalnya. Salah satu kegiatannya yakni memberikan jasa pembayaran tagihan otomatis dengan cara debet saldo langsung sesuai bill yang muncul dari rekening nasabah atau perbankan sering menyebutnya dengan istilah preauthorized debit, dan nasabah tidak perlu lagi pergi ke bank untuk mendatangi teller dalam melakukan pembayaran. Selain dapat mempermudah nasabah, sistem tersebut akan memberikan fee atau keuntungan tambahan bagi bank dari hasil kegiatan tersebut. Oleh karenanya, penerapan preauthorized debit memungkinkan untuk memperoleh fee tambahan lebih besar bagi bank syariah.

Fee tambahan bagi bank serta kemudahan yang nasabah rasakan keduanya saling memberikan manfaat. Oleh karena itu pemanfaatan sistem ini dapat diaplikasikan disetiap bank syariah yang ada dengan terus meningkatkan inovasi sistem dan pelayanan optimal agar keduanya (bank dan nasabah) sama-sama mendapatkan manfaat sesuai apa yang diharapkan. Akan tetapi, penerapannya di perbankan syariah mungkin belum begitu banyak diketahui oleh nasabahnya. Ketidaktahuan tersebut juga dirasakan 
peneliti sebagai nasabah salah satu bank syariah dengan tidak mengetahui akan adanya sistem tersebut. Maka dari itu, pengetahuan tentang hal ini ingin peneliti ketahui lebih lanjut, khususnya pada persepsi praktisi perbankan syariah mengenai sistem ini yang belum banyak diketahui nasabah.

\section{MATERI DAN METODE}

Kamus psikologi menjelaskan arti persepsi sebagai sebuah proses mengenali suatu obyek dan kejadiannya melalui panca indera, kesadaran dari proses-proses organis, penambahan berbagai arti dari kelompok penginderaan manusia yang timbul pada kejadian di waktu lampau, suatu variabel yang dapat melakukan pembeda diantara semua perangsang dengan menghalngi variabel yang masuk, dan merupakan kesadaran berfikir terhadap suatu keyakinan dan kebenaran mengenai hal yang didapat. (Chaplin, 2006:358). Segala hal yang terjadi pada saat proses transfer informasi menuju otak manusia juga merupakan persepsi. Manusia akan terus-menerus mengadakan hubungan menggunakan indera penciuman, pendengaran, penglihatan, dan peraba dengan lingkungan melalui persepsi. (Slameto, 2010:102).

Persepsi dalam Islam menjelaskan panca indera sebagai reseptor adalah langkah pertama proses penerimaan stimulus dalam proses persepsi tidak berfungsi dengan baik secara langsung setelah manusia lahir, tetapi akan berfungsi mengikuti perkembangan pendengaran fisiknya. Allah SWT dalam Al-quran surat An-Nahl ayat 78, AsSajdah ayat 9, dan Al-Isra' ayat 36 menjelaskan bahwa manusia dilahirkan ke dunia tidak langsung diberikan pengetahuan apapun. Selanjutnya Allah SWT mulai memberikan penglihatan, pendengaran, dan hati agar manusia mampu memperoleh suatu informasi yang menimbulkan berbagai persepsi berbeda diantaranya. Akan tetapi Allah SWT mengingatkan kepada seluruh manusia agar menyandarkan persepsi yang diungkapkan pada dasar ilmu pengetahuan, sebab fungsi dari indera berupa pendengaran, penglihatan, dan perasaan hati yang telah diberikan Allah SWT, kelak pertanggungjawabannya akan diminta dan dihisab. Maka manusia harus dapat mempersepsikan sesuatu menggunakan dasar ilmu yang jelas agar bermanfaat dan dapat dipertanggung jawabkan. (Najati, 2004:135).

Preauthorized debit adalah sebuah sistem yang menggabungkan informasi dan teknologi pada bank digunakan untuk sistem pembayaran tagihan nasabah secara otomatis. Pembayaran akan langsung didebit dari akun rekening secara rutin setiap tanggal tertentu, seperti pembayaran tagihan pembiayaan, leasing, pemakaian listrik, telepon, air, dan tagihan lainnya yang dimiliki nasabah. (Nurastuti, 2011:127). Pemakaian preauthorized debit dapat memberikan keuntungan berupa feebagi bank. Fee merupakan bentuk keuntungan bank yang dipeoleh dari berbagai transaksi atau jasa-jasa lain yang bank tawarkan selain dari spread based. (Kashmir, 2001:109)

Peneletian ini merupakan penelitian deskripif kuantitatif dengan memberikan penjelasan mengenai pesepsi praktisi perbankan mengenai penerapan preauthorized debit menggunakan teknik perhitungan. Populasi penelitian terdiri dari praktisi perbankan syariah kota Bogor dan Cianjur. Adapun sampel penelitian sebanyak 45 orang praktisi di sekitar kota Bogor dan Cianjur yang dipilih menggunakan teknik probability sampling.

Data penelitian terdiri atas data primer, berasal dari jawaban kuesioner yang dibagikan kepada responden dan wawancara secara langsung serta data 
sekunder yang didapatkan dari beberapa literatur dan data dari instansi terkait. Metode kuesioner dipakai untuk mempelajari karakteristik, perilaku, sikap, dan keyakinan responden terhadap pernyataan-pernyataan terkait yang diajukan. Pernyataan tersebut diantaranya berupa data responden untuk mengetahui karakteristik praktisi perbankan syariah, pernyataan umum mengenai bank syariah untuk mengetahui persepsi praktisi terhadap bank syariah, dan pernyataan spesifik untuk mengetahui sejauh mana pengetahuan praktisi tentang penerapan preauthorized debit di bank syariah. Untuk memperoleh data yang lebih jelas, selanjutnya dilaukan wawancara terhadap responden sebagai pelengkap jawaban atas pernyataan-pernyataan yang dimuat dalam kuesioner.

Teknik pengelolaan dan analisis data dilakukan dengan berbagai metode secara bertahap. Pertama dilakukan uji validitas untuk menguji bahwa pemakaian alat ukur tepat untuk digunakan dan cenderung stabil menghasilkan yang serupa setelah digunakan beberapa kali terhadap responden atas jawaban kuesioner yang berbeda satu sama lain dan uji reliabilitas untuk mengetahui tingkat reliability dan efektifitas setiap pernyataan dalam kuesioner. Kedua analisis statistik deskriptif menggunakan skala likert sebagai pengukur persepsi, pendapat, dan sifat seseorang atau kelompok agar dapat dideskripsikan secara terperinci. Terakhir dilakukan tes chi-square untuk menentukan hasil hipotesis penelitian.

\section{HASIL DAN PEMBAHASAN}

\section{Karakteristik Responden}

Tabel 1. Karakteristik responden

\begin{tabular}{lll}
\hline Karakteristik & Uraian & Jumlah \\
Jenis kelamin & Laki-laki & 22 \\
& Perempuan & 23 \\
\hline \multirow{2}{*}{ Tingkat } & Diploma & 5 \\
pendidikan & Sarjana & 39 \\
& Magister & 1
\end{tabular}

Sumber: Hasil Penelitian (diolah Tahun 2016)

Dari tabel diatas, diketahui jumlah responden perempuan lebih banyak satu orang atas responden laki-laki. Dapat dilihat bahwa jumlah responden antar keduanya hampir seimbang, dengan persentase poin sebesar $48.89 \%$ untuk responden laki-laki dan $51.11 \%$ untuk respoonden perempuan. Keadaan tersebut terjadi karena antara laki-laki dan perempuan mempunyai kesempatan yang sama untuk dapat menjadi seorang praktisi di bank syariah.

Tingkat pendidikan praktisi didominasi oleh lulusan tingkat strata 1 (S1) sebanyak 39 responden (86.67\%), tingkat diploma (D3) sebanyak lima responden (11.11\%), dan tingkat magister (S2) berjumlah satu orang (2.22\%). Tingkat diploma berada pada pendidikan terendah dikarenakan untuk menjadi praktisi bank syariah minimal adalah lulusan diploma (D3).

\section{Analisis Data}

\section{A. Uji validitas dan reliabilitas}

Hasil pengujian menunjukkan bahwa dengan derajat kebebasan $(\mathrm{df})=\mathrm{n}-2,45$ $2=43$ dan taraf signifikan $5 \%$ pada tabel 4.6, diperoleh hasil $r$ tabel $=0.248$. Maka dapat diketahui dari penyebaran 27 pernyataan kuesioner kepada responden terdapat 23 pernyataan kuesioner yang dikatakan valid ( $\mathrm{r}$ hitung $>\mathrm{r}$ tabel). Artinya ada 4 pernyataan kuesioner yang dinyatakan tidak valid ( $\mathrm{r}$ hitung $<\mathrm{r}$ tabel), yaitu pernyataan pada variabel A1, A2, A4, dan A6. Adapun hail uji reliabilitas menunjukkan nilai 
Cronbach's Alpha adalah $0.935>0.60$. Artinya setiap pernyataan-pernyataan yang dimuat dalam kuesioner sangat baik dan reliabel.

\section{B. Perhitungan Skala Likert}

Tabel 2. Persepsi Praktisi Perbankan Syariah mengenai Bank Syariah

\begin{tabular}{lllll}
\hline $\begin{array}{l}\text { Respon } \\
\text { Praktisi }\end{array}$ & F & $\begin{array}{l}\text { Skor } \\
(\mathrm{x})\end{array}$ & Fx & $M=\frac{\Sigma \mathrm{f}(\mathrm{x})}{\mathrm{n}}$ \\
\hline $\begin{array}{l}\text { Sangat } \\
\text { Setuju }\end{array}$ & 27 & 4 & 108 & \\
$\begin{array}{l}\text { Setuju } \\
\text { Kurang }\end{array}$ & 17 & 3 & 51 & $M=\frac{161}{45}$ \\
$\begin{array}{l}\text { Setuju } \\
\text { Tidak }\end{array}$ & 1 & 2 & 2 & \\
$\begin{array}{l}\text { Setuju } \\
\text { Jumlah }\end{array}$ & 0 & 1 & 0 & $=3.58$ \\
\hline
\end{tabular}

Sumber : hasil penelitian (diolah tahun 2016)

Penelitian menghasilkan data seperti pada tabel 4.8, yakni diperoleh sebanyak 27 atau $60 \%$ responden memberi pernyataan sangat setuju, sebanyak 17 atau $37.78 \%$ menyatakan setuju, sebanyak 1 atau $2.22 \%$ menyatakan kurang setuju, dan tidak terdapat respon tidak setuju dari total 45 responden terhadap pernyataan mengenai Pengetahuan Umum Praktisi Perbankan Syariah Mengenai Perbankan Syariah. Serta diperoleh hasil angka penafsiran M $=3.58$, menunjukkan bahwa jawaban rata-rata setiap responden adalah "sangat setuju". Pernyataan yang diajukan diantaranya adalah mengenai penerapan prinsip syariah pada kegiatan operasional bank, sistem dan kegiatan utama bank syariah, perbedaan antara bank konvensional dengan syariah, peminatan terhadap produk fee based sampai kepada penggunaan teknologi sesuai dengan perkembangan yang paling mutakhir saat ini. Diantara semua responden, rata-rata menjawab pilihan sangat setuju atas seluruh pernyataan dalam kuesioner. Responden berpendapat bahwa saat ini semua bank syariah telah menerapkan prinsipprinsip syariah yang dianjurkan Islam secara hati-hati dalam menjalankan kegiatannya, meskipun beberapa dari praktisi beranggapan bahwa kenyataannya prinsip tersebut masih belum diterapkan sepenuhnya dalam bebeapa hal. Namun, dalam hal kegiatan utama, penggunaan teknologi dalam setiap kegiatan bank syariah, sampai kepada perbedaannya dengan bank konvensional, responden memberikan jawaban setuju secara keseluruhan mengenai semuanya. Pengetahuan responden akan perbankan syariah didapat ketika mereka mulai menjadi karyawan bank syariah lewat pelatihan dan pendidikan yang diberikan pihak terkait. Bahkan dari sebagian mereka pengetahuan tentang hal tersebut didapat ketika belajar di perguruan tinggi.

Tabel 3. Persepsi Praktisi Perbankan Syariah mengenai Preauthorized debit pada Perbankan Syariah

\begin{tabular}{lllll}
\hline $\begin{array}{l}\text { Respon } \\
\text { Praktisi }\end{array}$ & F & $\begin{array}{l}\text { Skor } \\
(\mathrm{x})\end{array}$ & Fx & $M=\frac{\Sigma \mathrm{f}(\mathrm{x})}{\mathrm{n}}$ \\
\hline $\begin{array}{l}\text { Sangat } \\
\text { Setuju }\end{array}$ & 27 & 4 & 108 & \\
$\begin{array}{l}\text { Setuju } \\
\text { Kurang }\end{array}$ & 17 & 3 & 51 & $M=\frac{161}{45}$ \\
$\begin{array}{l}\text { Setuju } \\
\text { Tidak }\end{array}$ & 1 & 2 & 2 & \\
$\begin{array}{l}\text { Setuju } \\
\text { Jumlah }\end{array}$ & 0 & 1 & 0 & $=3.58$ \\
\hline Sumber : hasil penelitian (diolah tahun 2016)
\end{tabular}

Berdasarkan tabel 4.9, diperoleh sebanyak 10 atau $22.22 \%$ praktisi mengatakan sangat tahu, 28 atau 62.22 $\%$ mengatakan tahu, 6 atau $13.33 \%$ mengatakan kurang tahu, dan ada yang menjawab tidak tahu sejumlah 1 orang atau $2.22 \%$ dari total 45 responden terhadap pernyataan mengenai Pengetahuan Praktisi tentang Sistem Preauthorized debit. Serta diperoleh hasil angka penafsiran $\mathrm{M}=3.04$, memperlihatkan bahwa praktisi memberikan persepsi "tahu" mengenai Preauthorized debit di bank syariah. Pada pernyataan-pernyataan mengenai 
preauthorized debit yang diajukan, ratarata responden menjawab tahu. Mereka juga menyebutkan bahwa praktisi perbankan pasti telah mengetahui akan sistem preauthorized debit, namun dengan penyebutan istilah yang berbeda, yakni praktisi lebih mengetahuinya dengan istilah sebutan sistem auto debit. Pada dasarnya, sistem tersebut samasama merupakan debet saldo rekening secara otomatis pada setiap waktu tertentu dengan nominal sesuai tagihan yang tertera pada biller. Setelah selanjutnya dilakukan wawancara, bank tempat praktisi tersebut bekerja sudah menerapkan preauthorized debit. Jadi semua praktisi khususnya divisi operasional mengetahuinya karena di bank tersebut apabila ada pengajuan pembiayaan dari nasabah pasti akan memakai sistem tersebut untuk pembayaran angsuran.

Tabel 4. Persepsi Praktisi Perbankan Syariah mengenai Manfaat Preauthorized debit Perbankan Syariah

\begin{tabular}{lllll}
\hline $\begin{array}{l}\text { Respon } \\
\text { Praktisi }\end{array}$ & F & $\begin{array}{l}\text { Skor } \\
(\mathrm{x})\end{array}$ & $\mathrm{Fx}$ & $M=\frac{\mathbb{Z f}(\mathrm{x})}{\mathrm{n}}$ \\
\hline Sangat Set & 27 & 4 & 108 & \\
Uju & 17 & 3 & 51 & $M=\frac{161}{45}$ \\
Setuju & 1 & 2 & 2 & \\
Kurang Setuju & 0 & 1 & 0 & $=3.58$ \\
Tidak Setuju & 0 & & 161 & \\
Jumlah & 45 & & \\
\hline
\end{tabular}

Sumber : hasil penelitian (diolah tahun 2016)

Berdasarkan tabel 4.10, diperoleh sebanyak 13 atau $28.89 \%$ karyawan berpendapat sangat setuju, sebanyak 26 atau $57.78 \%$ berpendapat setuju, serta sebanyak 6 atau $13.33 \%$ memberikan persepsi kurang setuju. Sedangkan pada pernyataan tentang ini, tidak diperoleh jawaban tidak setuju dari seluruh responden. Dari hasil angka penafsiran $\mathrm{M}=3.16$, mendeskripsikan bahwa persepsi setiap praktisi bank syariah mengenai Manfaat Preauthorized debit adalah "Setuju". Praktisi yang diberikan kuesioner tentang manfaat yang akan bank peroleh dari preauthorized debit, memberikan pendapat setuju terhadap pernyataan-pernyataan yang dipaparkan dalam kuesioner. Pernyataanpernyataan tersebut diantaranya responden setuju bahwa preauthorized debit dapat memberikan fee cukup tinggi, pengendapan saldo rekening nasabah dapat diusahakan kembali oleh bank agar memperoleh keuntungan lain, memudahkan nasabah pada saat pembayaran tagihan, lebih efisien waktu karena tidak perlu mendatangi counter pembayaran, dan lain-lain. Dengan jawaban setuju dari setiap responden menandakan bahwa rata-rata pegawai bank syariah telah mengatahui tentang preauthorized debit dari mulai penerapan sampai pada manfaat yang oleh masing-masing pihak akan peroleh, karena preauthorized debit sudah diterapkan cukup lama, oleh karena itu manfaatnya sudah mereka rasakan sendiri.

\section{Tes Chi-Square}

Tabel 5. Hasil Uji Chi-Square Persepsi

Praktisi Perbankan Syariah mengenai Perbankan Syariah

\begin{tabular}{llll}
\hline $\begin{array}{l}\text { Respon } \\
\text { Praktisi }\end{array}$ & Fo & Fh & $\frac{(\text { Fo }- \text { Fh })^{2}}{\text { Fh }}$ \\
\hline Sangat Setuju & 27 & 15 & 9.6 \\
Setuju & 17 & 15 & 0.27 \\
Kurang & 1 & 15 & 11.27 \\
Setuju & 0 & 0 & 0 \\
Tidak Setuju & 0 & 45 & 21.14 \\
Jumlah & 45 &
\end{tabular}

Sumber : hasil penelitian (diolah tahun 2016)

Hasil penelitian sesuai pada tabel 4.11, diperoleh perhitungan chi-square hitung sebesar 34.01 dengan df (degree of freedome) $=\mathrm{n}-1=4-1=3$. Berdasarkan $\mathrm{df}=3$ dengan taraf signifilansi sebesar $5 \%$, maka diperoleh nilai chi-square tabel sebesar 7.815. Maka diketahui nilai chi-square hitung lebih besar dari nilai chi-square tabel (21.14 > 7.815). Dengan demikian HO ditolak dan $\mathrm{H} 1$ diterima, artinya bahwa para praktisi bank syariah telah mengetahui secara umum mengenai 
perbankan syariah. Hasil tersebut seimbang dengan perhitungan angka penafsiran dengan nilai yang diperoleh sebesar 3.4 menunjukkan bahwa persepsi pegawai bank syariah mengenai perbankan syariah adalah "sangat setuju". Namun, setelah selanjutnya dilakukan wawancara lebih intensif dengan responden, tanggapan mengenai prinsip-prinsip syariah Islam yang seharusnya diterapkan bank syariah ternyata masih ditegakkan dengan tidak sepenuhnya. Artinya, saat ini antara praktek dan teori tidak ada keselarasan dalam menjalankan kegiatan yang seharusnya dijalankan berdasarkan teori dan panduan yang ada. Salah contohnya yaitu cenderung menggunakan akad tijarah daripada akad tabarru dalam pelaksanaan transaksi keuangan di bank syariah.

Tabel 6. Hasil Uji Chi-Square Persepsi Praktisi Perbankan Syariah mengenai Preauthorized debit pada Bank Syariah

\begin{tabular}{llll}
\hline $\begin{array}{l}\text { Respon } \\
\text { Praktisi }\end{array}$ & Fo & Fh & $\frac{(\text { Fo }- \text { Fh })^{2}}{\text { Fh }}$ \\
\hline Sangat Setuju & 27 & 11.25 & 0.14 \\
Setuju & 17 & 11.25 & 24.94 \\
Kurang & 1 & 11.25 & 2.45 \\
Setuju & 11.25 & 9.34 \\
Tidak Setuju & 0 & 45 & 36.87 \\
Jumlah & 45 & 45 \\
\hline
\end{tabular}

Sumber : hasil penelitian (diolah tahun 2016)

Berdasarkan perolehan hasil pada tabel 4.12, diperoleh perhitungan chisquare hitung sebesar 36.87 dengan $\mathrm{df}$ (degree of freedome) $=n-1=4-1=3$. Berdasarkan df $=3$ dengan taraf signifilansi sebesar $5 \%$, maka diperoleh nilai chi-square tabel sebesar 7.815. Maka diketahui nilai chi-square hitung lebih besar dari nilai chi-square tabel (36.87 > 7.815). Dengan demikian HO ditolak dan H1 diterima, artinya bahwa para praktisi perbankan syariah sudah mengetahui mengenai penerapan preauthorized debit pada perbankan syariah. Hal tersebut selaras dengan perhitungan angka penafsiran yang memperoleh nilai sebesar 3.04 memperlihatkan bahwa persepsi masing-masing praktisi bank syariah mengenai penerapan preauthorized debit adalah "tahu". Hal ini dikarenakan praktisi memang diharuskan mengetahui produk dan kegiatan operasional bank syariah.

Menurut responden, preauthorized debit dapat digunakan pada nasabah yang memiliki pembiayaan ataupun tidak. Bagi nasabah yang memiliki pembiayaan, sistem preauthorized debit akan langsung aktif dengan otomaatis tanpa harus ada pengajuan terlebih dahulu kepada pihak bank. Untuk yang tidak memiliki pembiayaan, nasabah harus mengajukannya terlebih dahulu kepada pihak bank agar sistem tersebut aktif. Biasanya preauthorized debit digunakan nasabah untuk melakukan pembayaran tagihan yang sifatnya rutin setiap bulan. Sehingga nasabah tidak perlu pergi ke counter pembayaran dan langsung dibayarkan oleh bank melalui pendedebetan pada rekening nasabahnya.

Selain pada tagihan PLN, Telkom, dan PDAM, untuk dapat memanfaatkan preauthorized debit secara menyuluruh, bank dapat menerapkannya kepada layanan jasa lain bank yang menyangkut dengan pembayaran setiap tagihan pelanggan seperti halnya pembayaran asuransi dan leasing. Akan tetapi bank harus mampu bekerja sama dengan setiap perusahaan dari masing-masing lembaga keuangan tersebut, yakni dengan tidak hanya bekerja sama dengan beberapa perusahaan saja. Karena tidak semua nasabah memilih perusahaan asuransi maupun leasing yang sama. Maka secara otomatis memungkinkan nasabah bank syariah yang memiliki tagihan di berbagai perusahaan asuransi dan leasing akan memanfaatkan sistem tersebut untuk mempermudah pembayarannya. 
Sebagai contoh, pada saat ini sedang ramai masyarakat yang mengikuti dan berpartisipasi dalam penggunaan jaminan sosial BPJS, khususnya BPJS kesehatan. Layanan BPJS kesehatan ini digunakan oleh berbagai kalangan menengah keatas karena memperoleh jaminan kesehatan di berbagai klinik kesehatan dan rumah sakit dengan cara memberikan iuran setiap bulannya sesuai dengan jumlah yang ditentukan kepada pihak BPJS. Maka dari itu, bank dapat memanfaatkan momen ini untuk menjalin kerja sama dengan pihak BPJS agar pelanggannya dapat melakukan pembayaran di bank syariah. Setelah kerja sama tersebut dapat direalisasikan, maka bank dapat menawarkan kepada nasabahnya yang memiliki tagihan BPJS kesehatan untuk dapat melakukan pembayaran secara preauthorized debit di bank syariah.

\section{Uji Chi-Square Persepsi Praktisi Perbankan Syariah mengenai Manfaat Preauthorized debit pada Perbankan Syariah}

Tabel 7. Hasil Uji Chi-Square Persepsi Praktisi Perbankan Syariah mengenai Preauthorized debit pada Bank Syariah

\begin{tabular}{llll}
\hline $\begin{array}{l}\text { Respon } \\
\text { Praktisi }\end{array}$ & Fo & Fh & $\frac{(\text { Fo }- \text { Fh })^{2}}{\text { Fh }}$ \\
\hline Sangat & 27 & 15 & 0.27 \\
Setuju & 17 & 15 & 8.07 \\
Setuju & 15 & 3.27 \\
Kurang & 1 & 15 \\
Setuju & & & \\
Tidak & 0 & 0 & 0 \\
Setuju & 45 & 45 & 11.61 \\
Jumlah & 45
\end{tabular}

Sumber : hasil penelitian (diolah tahun 2016)

Berdasarkan hasil penelitian pada tabel diatas, diperoleh perhitungan chisquare hitung sebesar 11.61 dengan df (degree of freedome) $=n-1=4-1=3$. Berdasarkan $\mathrm{df}=3$ dengan taraf signifilansi sebesar $5 \%$, maka diperoleh nilai chi-square tabel sebesar 7.815.
Maka diketahui nilai chi-square hitung lebih besar dari nilai chi-square tabel (11.61 > 7.815). Dengan demikian HO ditolak dan $\mathrm{H} 1$ diterima, artinya bahwa para praktisi perbankan syariah sudah mengetahui mengenai manfaat penerapan Preauthorized debit pada perbankan syariah. Hal tersebut berbanding lurus dengan perhitungan angka penafsiran dengan perolehan nilai sebesar 3.16 menunjukkan bahwa persepsi praktisi perbankan syariah mengenai manfaat penerapan Preauthorized debit pada perbankan syariah adalah "setuju".

Menurut responden, preauthorized debit mejadi salah satu sistem yang memanfaatkan teknologi mutakhir saat ini untuk dapat memberikan berbagai manfaat bagi berbagai pihak yang menggunakannya. Diantaranya adalah bank memperoleh pendapatan berupa fee dari jasa kemudahan pembayaran tagihan bagi nasabah, nasabah memperoleh kemudahan dan kelancaran dalam melakukan pembayaran tagihan, dan lain sebagainya. Akan tetapi, hal tersebut dapat tercapai apabila nasabah bersikap kooperatif dengan tidak membiarkan saldo rekeningnya dalam keadaan kosong.

\section{KESIMPULAN DAN IMPLIKASI}

Setelah melakukan penelitan mengenai "Persepsi Praktisi Perbankan Syariah Mengenai Penerapan Teknologi Preauthorized debit Sebagai Fee Based Income Pada Bank Syariah" maka, penelitian ini dapat disimpulkan sebagai berikut:

1. Para praktisi perbankan syariah sudah mengetahui mengenai penerapan preauthorized debit pada bank syariah. Hal ini berdasarkan pada analisis perhitungan chi-square yang dilakukan dengan hasil chisquare hitung lebih besar daripada chi-square tabel (36.87 > 7.815). 
Maka H0 ditolak dan H1 diterima, artinya para praktisi perbankan syariah sudah mengetahui penerapan preauthorized debit pada bank syariah.

2. Manfaat yang diperoleh dari penerapan preauthorized debit diantaranya : Preauthorized debit dapat memberikan fee cukup tinggi bagi bank, memberikan kemudahan bagi nasabah dalam melakukan pembayaran tagihan, membantu kelancaran nasabah dalam melakukan pembayaran tagihan agar tepat waktu, dan lain sebagainya.

\section{DAFTAR PUSTAKA}

Slameto. 2010.Belajar dan Faktor-faktor yang Mempengaruhinya. Jakarta: PT Rineka Cipta, 2010.

Chaplin, J. P. 2006. Kamus Lengkap Psikologi (Kartini Kartono, Trans.). Jakarta: PT. Raja Graindo Persada.

Nurastuti, W. 2011. Teknologi Perbankan. Yogyakarta: Graha Ilmu.

Najati, M. U. 2004. Psikologi dalam Perspektif Hadits. Jakarta: Pustaka.

Kasmir. 2001. Manajemen Perbankan. Jakarta: Raja Grafindo Persada. 